\title{
FROM SEGREGATION TO CELEBRATING DIVERSITY
}

\author{
Ilona Bruveris \\ University of Notre Dame, Australia
}

\begin{abstract}
The move from segregation of students with behaviour difficulties to one of inclusion required teachers to make a significant paradigm shift. This paper reviews the strategies used by the New South Wales state education department to facilitate, over time, paradigm shifts in teacher thinking. Are there factors which limit the success of these strategies? What can be learnt from this?
\end{abstract}

Keywords: student behaviour, inclusion, teacher professional learning, education policies.

\section{Introduction}

Do we really want to celebrate diversity when it comes to students who are experiencing difficulties with following rules, accepting consequences, interacting and communicating in a classroom setting? Such students, who are usually labelled as having an emotional disturbance or behaviour disorder (EBD), are the ones whom teachers find challenging (Kauffman \& Landrum, 2009) and who can add to the teachers' stress levels and dissatisfaction with their career (Melnick \& Meister, 2008). How can we support teachers to make the paradigm shift necessary to include these students in the classroom and in the celebration of diversity? Does professional learning do the trick?

This paper will review the transition from segregation to inclusion by the New South Wales (NSW) state education department, currently known as The Department of Education and Communities (DEC). It will identify the services and strategies that relate to students with behavioural difficulties that have been part of the Department's strategy to help teachers adjust to, and comply with, new policies culminating in celebrating diversity and review professional learning since the 1980s.

Changes to the dominant discourse surrounding the education of students whose behaviour impacts on classroom coherence and management have required teachers to undergo paradigm shifts in their beliefs about the education of such students, how teachers view their classrooms, their role and the responsibilities of other students in the class in the inclusion equation. In NSW, the DEC has used teacher professional learning to assist with the implementation of the new policies and with each shift in the dominant discourse has introduced new courses, modules and readings. They have 
complimented this with additional resources such as special classes, known as support classes in NSW, in regular schools and in special schools, known as Schools for Specific Purposes, along with introducing additional support personnel. A raft of policy documents has guided the whole process. However, is this sufficient to achieve the necessary paradigm shift?

\section{Aim of the study}

This study aims to identify what strategies have been employed by the DEC to encourage teachers to make a paradigm shift from segregation to inclusion as well as what these strategies teach us.

\section{Method}

This paper is based upon an analysis of DEC policy documents and support services. Current theories on inclusion, professional learning and educational change management have guided the analysis and discussion.

\section{The dominant discourse}

Almost from the earliest days of public education in NSW, the dominant discourse concerning the education of students with EBD has been one of a deficit model. The label emotionally disturbed/behaviour disordered says it all. It is the student who has the problem. This works against including students with EBD in regular settings. The medical model focuses on a causal relationship. Students can be seen as different from their peers, as the "other" one in the class (Van Swet, Wichers-Bot \& Brown, 2011). "A concern raised about mainstream policies and practices related to student behaviour is that they invariably locate 'the problem' within individual students, rather than in the context of classrooms" (Sullivan, Johnson, Owens and Conway, 2014, 4) therefore the responsibility for change rests with the student. Furthermore, labelling can lead some teachers to doubt whether they are qualified to teach students with disabilities (Slee, 2001). According to Senge (2014) "The biological world teaches that sustaining change requires... addressing (of) the limits that keep change from occurring." (p. 8) The use of labels for identification and placement of students with disabilities, regardless of the nature of the disability, is a limiting factor and one that works against any paradigm shift by teachers. It was only in the 2000s that the DEC embraced a social model which reflected student needs, environmental adjustments, teacher professional judgements and personalised learning plans. 


\section{Then and now: public education in NSW and services for students with behaviour issues}

Education in NSW has been influenced by a range of factors both historical and cultural such as political instability and the convict beginnings of the colony (1788). It was not until 1848 that Governor Fitzroy was able to establish the National Board of Education which created a government education system. A segregationist approach towards education of students with aberrant behaviours was established when the Vernon Nautical Training ship was launched as a program for delinquent boys in 1886.

In 1880 the Public Instruction Act meant that the administration of the education system became the responsibility of the State through the Department of Public Instruction. The Public Instruction Act of 1880 has provided the framework for education in NSW since that time. (Wilkinson, 2008). Children had to attend school between the ages of six and fourteen, which became seventeen only in 2010. The Guildford Truant School, again segregating troublesome students, was established in 1918, as compulsory education brought with its own problems. Segregation continued when the Enmore Activity School (1936) was established to provide a three year course for adolescent boys with a normal IQ who were educationally backward or had bad behaviour problems.

After the Depression and World War II there was considerable pressure in Australia for economic and social reform. A new middle class had developed in Australia, one that could not provide a secure future for their children by taking them onto the land or into business. Industrialisation, the basis for the new postagricultural Australian economy, meant that job security for their children could be found in the growing public service, banking, retail and insurance industries. In response to this, from the 1950s through to the 1970s, each Australian state reformed or expanded their secondary school systems. During this period the first special school for students with emotional disturbance, Arndell, was established (1959) again segregating students whose behaviour challenged teachers.

The next major change to public education in NSW was the Wyndham Scheme, implemented from the early 1960s and based on establishing comprehensive high schools which did not determine their student intake on attainment or ability to pay fees and which prepared students for a broad range of post-school options. Gulson writes that there was an acceptance of the comprehensive schooling model as its aim was to allow all students to access equal educational opportunities and middle class parents favoured this. This is not surprising in an era which consisted of social movements, feminism and concern for the rights of the individual (Noyce, 1985).

In the 1960s and 1970s the quest continued for greater freedom and 
openness. Henry Schoenheimer, an Australian educational commentator of that time believed that it was time to question everything: structures, institutions and beliefs. Schiefelbusch (1986) refers to the 1970s and 1980s as the "Renegotiation Period" when boundaries between regular and special education were being renegotiated. This process is reflected in the establishment, from 1972, of Adjustment Classes, special classes for students with emotional disturbance, which were located in regular schools in NSW and allowed for integration, at least partial, into mainstream classes.

By the 1980s neoliberalism began to influence public policy, including education, and it has continued to do so into the twenty-first century (Gulson, 2007). Neoliberalism favours individual competition, accountability, management and efficiency (Acton \& Glasgow, 2015). If, as Declan McKenna notes, all policy processes are inherently political, the release of the Enrolment of Children with Disabilities policy and the Integration Statement in 1988 by the then Director-General of Education, is a valid example of how education was reflecting the neoliberal drive for efficiency, accountability and managerialism. It should be noted, however, that the policy also reflected the ideology of the time: that all children can be taught and that integration would allow students with disabilities to be part of a wider community.

Regardless of the aetiology, the era of integration of students with disabilities was firmly underway. Teachers had to make a paradigm shift with respect to students with disabilities including those with behavioural issues: if they continued to regard students with disabilities as the source of the problem, integration and later, inclusion, would be doomed to a half-hearted implementation without commitment. As later discussion will indicate, from the 1980s, as integration placed new demands on schools, the DEC offered direction through its policy documents and accompanied this with significant professional learning concerning the management of student behaviour. This was important as the greatest changes to the dominant discourse surrounding students with behaviour difficulties were yet to come with inclusion. "While older concepts, such as integration and mainstreaming, focused on how to integrate pieces into established wholes, inclusion became a quest for creating a whole" (Gorranson, Nilholm \& Karlsson, 2011, p. 541).

\section{The impact of legislature}

As Skrtic (Skrtc, 1991) argues, schools and systems need external pressure in order to bring about change. The DEC is bound by, at a national level, the Disability Discrimination Act 1992, the Disability Standards for Education 2005, National Disability Strategy 2010-2020 and the National Disability Insurance Scheme Act 2013. The Standards cover enrolment, parent choice, 
access and participation, curriculum development, accreditation and delivery, student support services, elimination of harassment and victimization. They include obligations for making reasonable adjustments to a student's learning program and environment. It should be noted here that the term "reasonable adjustments", however, allows schools to decline enrolments if such an enrolment would create undue hardships or interfere with the learning of other students, therefore, segregation of students with behaviour difficulties is still possible.

At a state level the DEC and its schools are also bound by the Ombudsman Act 1974, the Anti-discrimination Act 1997, and the Disability Inclusion Act 2014. These acts facilitated the move by the DEC from a disability category focus prevalent in the 1960-1970s to the current functional needs focus, where personalised learning adjustments are key.

\section{Achieving a paradigm shift: additional resources}

One way to support teachers to change their mindset is to assign additional resources geared at facilitating new procedures. A range of specialist services were created during the decades from the 1980s to the 2000s. Many of these services were available to schools to support the needs of students with any diagnosed disability, including emotional disturbance (Table 1). Some were specifically for students with EBD.

Table 1 Additional Services for NSW schools

\begin{tabular}{|c|l|l|l|}
\hline Date & \multicolumn{1}{|c|}{ Service } & \multicolumn{1}{c|}{ Description } & \multicolumn{1}{c|}{ Availability } \\
\hline 1980s & $\begin{array}{l}\text { Integration } \\
\text { Teachers } \\
\text { Integration Aides } \\
\text { Integration } \\
\text { Consultants }\end{array}$ & $\begin{array}{l}\text { Support integration of students with } \\
\text { disabilities into regular classes } \\
\text { Support integrated students } \\
\text { Assist with integration including with } \\
\text { applications for Commonwealth Schools } \\
\text { Commission Integration Funding for } \\
\text { individual students. }\end{array}$ & Regular schools \\
& $\begin{array}{l}\text { Resource } \\
\text { Teachers }\end{array}$ & $\begin{array}{l}\text { Work directly in schools with students and } \\
\text { teachers, initially withdrawing students but } \\
\text { later working in a team teaching model in } \\
\text { class }\end{array}$ & Regular schools \\
& $\begin{array}{l}\text { Itinerant Support } \\
\text { Teachers }\end{array}$ & $\begin{array}{l}\text { Work directly in schools with teachers } \\
\text { providing advice, modeling strategies in }\end{array}$ & Regular schools \\
\hline
\end{tabular}




\begin{tabular}{|c|c|c|c|}
\hline & $\begin{array}{l}\text { (Behaviour) } \\
\text { IST(B) } \\
\text { Support classes } \\
\text { (ED) }\end{array}$ & $\begin{array}{l}\text { class, helping to develop individual } \\
\text { behaviour plans but also whole class plans } \\
\text { Specialist classes established on a needs } \\
\text { basis for students with a diagnosis (ED) }\end{array}$ & $\begin{array}{l}\text { Usually } \\
\text { established in } \\
\text { regular schools }\end{array}$ \\
\hline $1990 \mathrm{~s}$ & 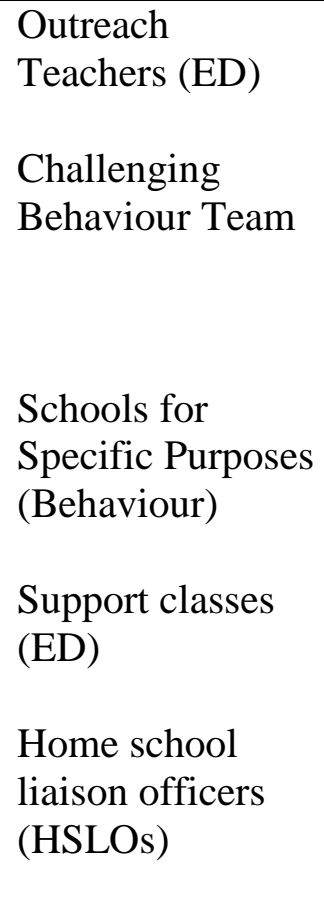 & $\begin{array}{l}\text { Work in a similar way to IST(B)s but can } \\
\text { only support students with an ED diagnosis } \\
\text { Advise class teachers re students with } \\
\text { moderate/severe disabilities and behaviour } \\
\text { difficulties often associated with specific } \\
\text { syndromes or autism } \\
\text { Established for students with no confirmed } \\
\text { diagnosis but with significant behaviour } \\
\text { disorders } \\
\text { Specialist classes established on a needs } \\
\text { basis for students with a diagnosis (ED) } \\
\text { Specially trained teachers who are } \\
\text { authorised attendance officers. They work } \\
\text { with schools, students and their families to } \\
\text { resolve attendance issues. }\end{array}$ & $\begin{array}{l}\text { Regular schools } \\
\text { Support classes } \\
\text { in regular or } \\
\text { special schools } \\
\text { Available for } \\
\text { students from } \\
\text { regular classes } \\
\text { Usually } \\
\text { established in } \\
\text { regular schools } \\
\text { All schools }\end{array}$ \\
\hline
\end{tabular}

The DEC has always maintained special schools but the nature of the needs of students attending these schools has changed significantly. In the 1980s the focus moved to integration rather than segregation. The aim was to return students to the least restrictive setting possible, usually to mainstream or regular classes, to re-integrate them. Support classes in regular schools, sometimes provided for partial integration into mainstream classes for some subjects. In the 1980s and 1990s such partial integration was not necessarily accompanied by any changes to the pedagogy, the school environment or the existing belief system about students with disabilities. The attempt was to create as little disruption to the functioning of the class as possible (Anderson, Klassen \& Georgiou, 2007). This did not require a significant teacher mind shift.

Once the dominant discourse became one of inclusion, it was no longer viable to maintain the status quo in the classroom and somehow fit in the student with the disability or disorder. Re-alignment of resources is a strategy used by DEC. The introduction of Every Student, Every School was accompanied, in 2013, by structural change. 1800 Learning and Support Teachers were allocated to schools, which was partially achieved by restructuring the existing itinerant and support teacher programs. The new Learning and Support Teachers work collaboratively with classroom teacher to support students with disabilities. 
Flexible funding to support students with disabilities was also made available to every regular school.

Another service which is important for students with behaviour difficulties is that of the school counsellor. Not only do they provide support for students and undertake psychological assessment, they also provide advice to the school executive and to classroom teachers. School counsellor numbers are increased but there is no formula for this. In 2015, $\$ 167$ million became available through the Supported Students, Successful Students project. This meant an increase of $45 \%$ (DEC data) of counselling and wellbeing services across NSW.

NSW has a very strong teacher union, The NSW Teachers' Federation. A continuing argument that the Federation has promulgated is the need to allocate additional resources to support new initiatives and from the Federation's perspective the additional resources are rarely sufficient.

\section{Achieving a paradigm shift: DEC policies}

The United Nations' Convention on the Rights of the Child (United Nations, 1991) describes the importance of protecting children's quality of life and their rights to be educated in a safe environment, free from all forms of violence, victimization, harassment, and neglect. In 1994 a national inquiry into school violence, aggression, and bullying commissioned by the Australian government concluded that although insufficient data were available from which to reliably estimate the extent of school violence, aggression, and bullying, bullying appeared to be a significant national problem (Commonwealth Government of Australia, 1994).

In 1996 the DEC released the Student Welfare, Good discipline and Effective learning Policy which was a revision of the Student Welfare Policy of 1986 which had stated that 'Student welfare' encompasses everything that a school community does to meet the personal and social needs of students. In 1996 this was modified to Student welfare in government schools encompasses everything the school community does to meet the personal, social and learning needs of students. This was the beginning of a move towards a co-ordinated educative approach to the issues surrounding behaviour. Prior to this behaviour management training had not focused on addressing curriculum and learning, it was all about the behaviours. It was an acknowledgement that a raft of additional programs and services were incomplete if learning needs were not also addressed. The focus on learning continued with the Quality Teaching model introduced in 2003. This stressed that the core business of teachers is pedagogy and for DEC there were three important aspects to pedagogy: it must focus on high levels of intellectual quality; there needs to be a quality learning environment; learning must be seen by students to have significance. It stressed 
that intellectual quality was just as important for all students including "students identified with special needs in mainstream classes" (Quality teaching in NSW public schools, Discussion paper, 2003, 7).

As well a key focus in the 1990s was how to make schools safe, physically and emotionally, and this added to the complexity of including students with behaviour difficulties. In July 2003 the National Safe Schools Framework (NSSF) was endorsed by all Australian ministers of education. The framework aimed to raise awareness of the importance of a shared vision of physical and emotional safety and wellbeing for all students in Australian schools. The DEC released, in 2005, the Student Discipline in Government Schools Policy. This policy required that each school develop its own school discipline policy and that this contained: the discipline code or school rules; strategies and practices to promote positive student behaviour, including specific strategies to maintain a climate of respect; strategies and practices to recognise and reinforce student achievement; strategies and practices to manage inappropriate student behaviour. A specific anti-bullying policy Bullying: Preventing and Responding to Student Bullying in Schools Policy followed in 2010. DEC has also released the Behaviour Code for Students, the latest version being in 2015.

The Every Student, Every School (2012) initiative introduced a learning and support framework to ensure personalised learning and support for any student with special needs. This initiative aimed to provide better support for students whose learning was impacted upon by disability. Personalised learning and support has four elements: collaboration; assessed individual need; adjustments and the impact of adjustments and is solution-focussed. As van Swet et al., (2011, p. 920) point out "the concept of using a solution-focused approach in an assessment process widens the prospect of potential results" and as there are no universal solutions, it leads the teacher to work in a reflective manner collaborating with parents, students, school personnel, peers and outside providers in order to determine learning needs and address these needs.

Another element is that of assessment. Each student is assessed to determine his or her individual needs Based on this, adjustments are made which are changes to curriculum, instruction and environments that are personalised against each student's assessed need. Finally the impact of the adjustments needs to be determined. Evidence is collected, analysed and interpreted in order to make a judgement about the value of the adjustments. This information informs further actions. As van Swet et al., (2011, p. 911) state, this means that "Diagnosis is no longer only conducted by individuals specifically trained for this purpose but, rather, within a cooperative network of teaching colleagues, parents, other professionals, organisations and the students themselves. This shifting assessment concept recognises the complexity of cognitive development 
and the need for many voices to understand challenges presented by individual learners". The limiting impact of labelling was being finally being assailed.

From 2015 it became mandatory for each school to take part in national disability data collection (National Consistent Collection of Data, NCCD) using evidence of personalised learning and support. Interestingly it is based on the professional judgement of teachers about their students.

Another document, The Wellbeing Framework, was release by DEC in 2015 and asks schools to build on the individual strengths of each student. DEC has moved to a strong welfare focus, from discussing student behavioural support needs because the students have been identified as emotionally disturbed, through the concept of student mental health to one of student wellbeing. The aim is to support students to "connect, succeed and thrive". The question is where can students best achieve this?

Every Student, Every School reflects the DEC's decision to define inclusion as applicable to both regular and special schools. Whilst seventy-seven percent of students with disabilities in NSW receive their education in regular schools (DEC, 2014 data), this document validates the existence of special schools as well. It is an acknowledgement of the confusion surrounding inclusive schooling as jurisdictions try to make sense of it with respect to their circumstances and needs. Every student, Every School acknowledges and celebrates diversity whether at a regular or special school but in doing so what is the impact on teachers making the necessary paradigm shift to accept that the student with behaviour difficulties is not the outsider, the one with the label but that he/she can contribute to the class environment. Similarly the teachers' union Special Education Position Paper (2014) states "The experience of teachers in mainstream schools confirms, however, that for a small but significant minority of students, no amount of adjustments within mainstream schools is sufficient to engage them in learning" (p. 1). Does this help to confront existing teacher beliefs about students with behaviour difficulties?

\section{Achieving a paradigm shift: professional learning}

Most research shows that the successful introduction of reforms is directly related to the implementation strategies used by teachers and their knowledge, skills, attitudes, beliefs and ability to collaborate (Florian, 2008). As teachers have a crucial role to play as change agents it is not surprising that the DEC over the years has invested significantly in a range of professional learning programs for teachers and school executive. With respect to students with behaviour difficulties, the 1980s saw opportunities for teachers to attend courses, to be coached in school, to try out new strategies with back-up in the school in the form of the IST(B) and to engage in collegial discussions. Neoliberalism 
brought with it less face-to-face contact and more training online and through video presentations, but it did put school-based individual teacher professional learning plans on the table. This meant that professional learning could be tailored to meet the needs of individual schools and, just as importantly, to individual teacher needs, therefore it should be possible to challenge and address assumptions about including students with behaviour difficulties with those teachers who need this.

Enrolment of Children with Disabilities stated that children with disabilities should attend regular neighbourhood schools "where it is possible and practical and $\mathrm{n}$ the best interests of the child" (Enrolment of Children with Disabilities, $1988,1)$. This was acceptable to teachers when it came to students with sensory impairment or other non-confronting needs but a very different matter for students with EBD. There was also the question of the best interests of the remaining students in the class. Students with EBD challenged the teacher not only to re-evaluate how they thought about the students but also themselves and their role.

"From my point of view, the teacher's professional self-concept has an important impact on how the classroom is constructed as a social practice and to what extent the classroom - and the teacher - can handle diversity" (Hansen, 2012). How a teacher thinks about, perceives or evaluates him/herself can change and is linked to how he/she develops and grows as a teacher. The educational change literatures emphasises that participation, information, education, communication, involvement, support and agreement are necessary for change (Dinham, 2008). However, teachers need more than these opportunities in order to accept and implement change. As Fulham \& Hargreaves (1991, p. 5.) point out teachers need to be provided with opportunities to "confront the assumptions and beliefs underlying their practices, avoid faddism" and to develop a common purpose through on-going discussions with one another. Individualised professional learning plans for teachers provide an opportunity for this.

In the 1980s DEC started to tackle teacher beliefs and practices through a series of professional learning projects. It has continued to so up until the present because it meets the DEC's need to change teacher thinking but also in an attempt to ensure that teachers are not betrayed by the latest "flavour of the month" program. The DEC was also influenced by the concerns of middle class parents had about school safety and their desire to ensure that their child's progress was not adversely affected by the inappropriate behaviour of others at school. These concerns led to a range of professional learning opportunities. The list below records some major initiatives but it is not exclusive (Table 2). There were many localised professional learning programs. 
Table 2 DEC professional learning resources to support classroom and behaviour management

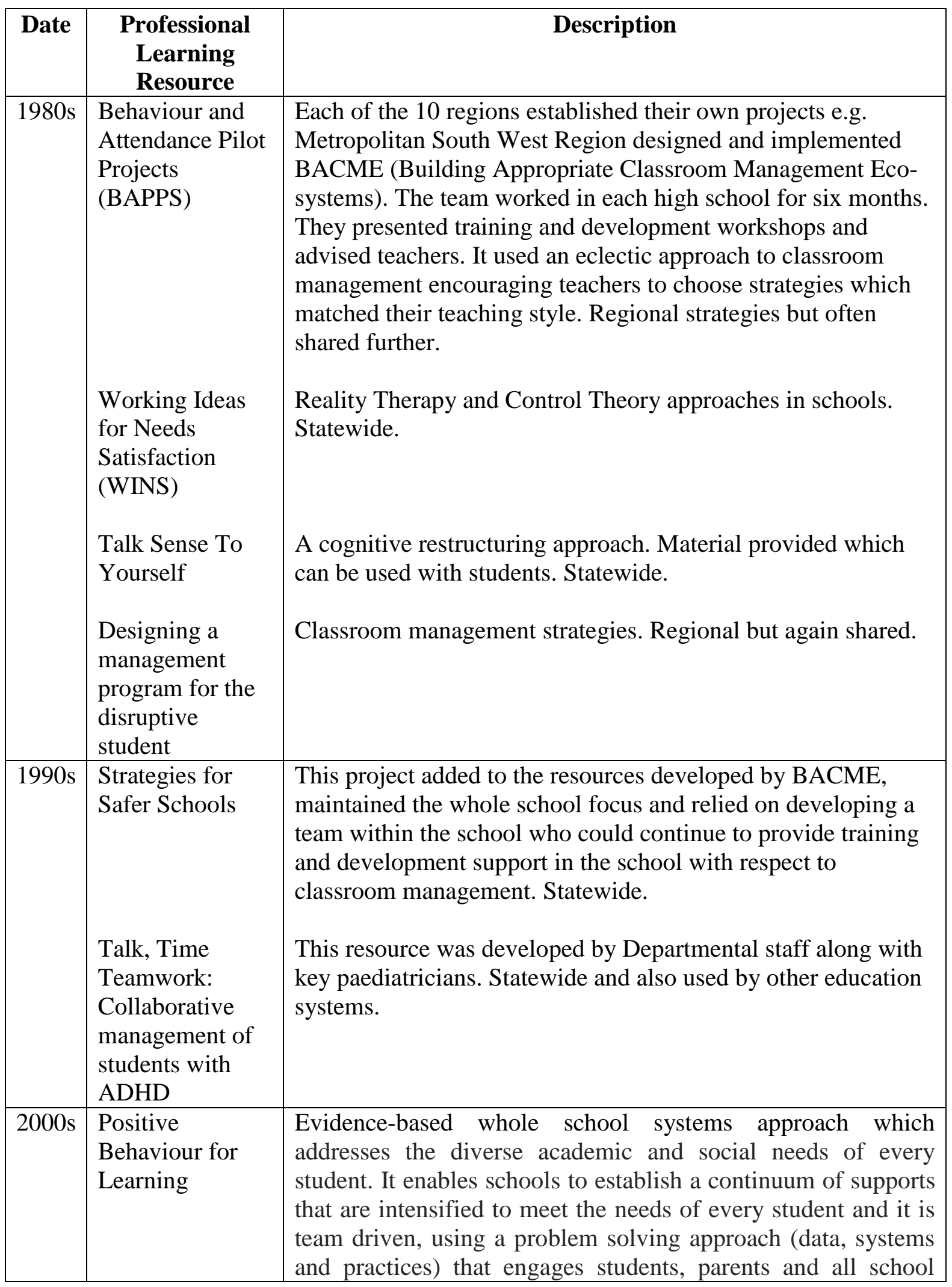




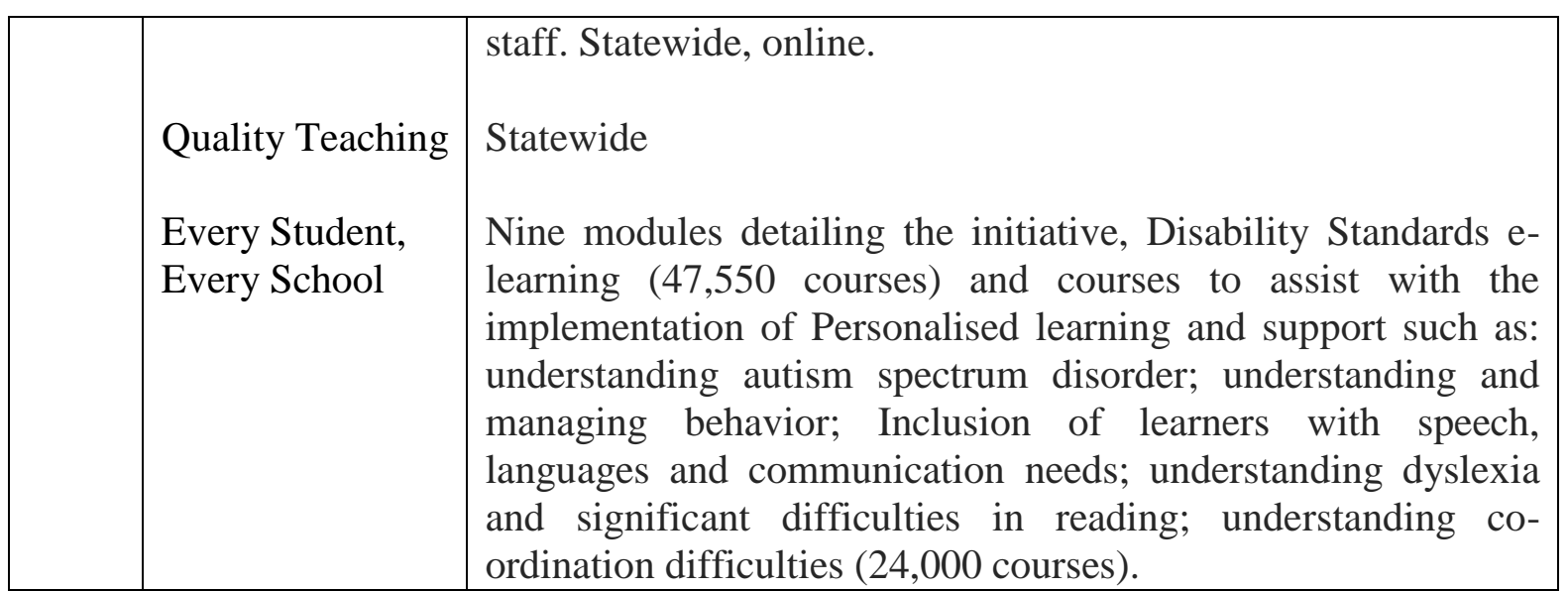

The 1990s brought a change in the way that issues about behaviour were expressed which was now in terms of school safety and Strategies for Safer Schools was introduced. Two elements are worthy of note. The economic climate had changed. Neoliberal economic considerations, along with theories of ownership of strategies by staff and schools, placed the focus on schools developing the skills to manage by themselves and not rely on a team of outside "experts". Similarly, the 2000s added a focus on teaching and learning, not just on behaviour strategies.

Additional professional learning is organised by schools as they are required to have incorporated professional learning into their school plan. As Ainscow \& Sandill (2010) state "...the starting point must be with staff members: in effect, enlarging their capacity to imagine what might be achieved, and increasing their sense of accountability for bringing this about. This may also involve tackling taken for granted assumptions, most often relating to expectations about certain groups of students, their capabilities and behaviours" (p. 402). School based professional learning makes this easier to achieve as it is personalised.

\section{Conclusion}

As Hansen (2012, p. 95) states "It is primarily the teacher who draws the line between inclusion and exclusion in the specific classroom. ... we should examine how the teacher constructs categories, teaching and classroom, because it is these constructions which decide the boundary between inclusion and exclusion". The DEC has been aiming to de-construct and then re-construct teacher beliefs and practices surrounding the inclusion of students with behaviour difficulties. Each decade has brought a shift in professional learning. The 1980s focussed on training that developed teacher/student interactions and relationships. The 1990s brought school safety into the equation and this meant 
that there was a greater concern with processes such as discipline codes and suspension procedures. This focus was complimented the 2000s by Quality Teaching, an acknowledgement of the role of teaching/learning activities, not just teaching new behaviours and social skills. This journey hasn't meant that prior strategies are dismissed, rather they are discussed using different language and built upon to make a new dominant discourse. The problem with this is that not all teachers are in a position to make a paradigm shift. As Farmer, Reinke and Brooks (2014) note: professional learning needs to encourage teachers to reflect on their current beliefs and practices; consider how new knowledge compliments these and have the opportunity to share with colleagues. The trend of teacher personalised professional learning plans and school designed professional development is a positive step towards this. It allows learning to be specific to teacher and school needs. As it is managed at the local level it can be used to target specific assumptions, teach new skills for specific situations and support the teacher to incorporate new practices into their routines. What can be learnt from the DEC's journey in professional learning is that, just like for the students, personalised is best. Professional development programs are often provided to facilitate change. However, not all professional development programs are effective (Fullan \& Hargreaves, 1991). Addressing the concerns of teachers is one of the principles for an effective professional development program (Hall \& Hord, 2001). While professional development may resolve some of the teachers' concerns, it may also intensify other types of concern and personalised learning can be used to address this.

However there are elements to professional learning that need consideration. If policies reflect the political reality and professional learning is used to support policy shifts, what is the implication of this for using this to achieve paradigm shifts? The DEC experience is indicative of being caught on a treadmill: I need expert help, I am the expert; students with a diagnosis belong in my class, these students need to be educated elsewhere. In the 1980s it encouraged a range of professional development opportunities most of which were based on expert knowledge, all of which taught teachers new skills, and hopefully, helped them achieve new understanding, but its continuation of segregated programs sent a message about students with behaviour difficulties and teacher ability to include them, it reinforced the "specialness" of these students. Then the 1990s brought in the element of school safety, a range of associated procedures and processes for managing inappropriate school behaviours which further reinforced the idea "they don't belong" for some teachers. The DEC encouraged schools to become experts in behaviour management through programs such as Strategies for Safer Schools but this program requires immense investment by teachers and a school leadership team, again leaving some teachers to prefer the students to be "fixed" or removed. 
Finally with Every Student, Every School, student personalised learning placed the teacher in a key position and required that the placement was accompanied by the necessary adjustments. This is a complex process and only once the National Consistent Collection of Data process has been in operation for a few years will it be possible to determine whether the process exists only on paper or is realised and teachers have made the paradigm shift.

This raises the issue of what messages are sent by the DEC by continuing placements in special schools, regardless how they are re-configured or relabelled. This is not intended to be a discussion of the value or otherwise of special schools. It is a question of the mixed message that is being sent, which is being reinforced by the Federation's statement on the need for segregated placements for some students: there are some students who cannot be included; and, with the Disability Standards for Education allowing school to decline enrolments due to the "reasonable adjustments" phrase, this seems a problem for achieving a paradigm shift by teachers away from the concept of segregation.

Novoa \& Yariv-Mashay (2015) wrote that in comparative education the focus should not be on the facts and realities as these cannot be compared. For complex comparisons the focus needs to be on the problem. If other systems are to take anything away from the DEC experience of moving to inclusion, it may be that the problem that really exists is the fusing of how to encourage teachers to pursue humanistic, inclusive approaches to teaching of all students, including those with behaviour difficulties, when the system's structure is based on techno-rational approaches and that professional learning is not sufficient under these circumstances.

\section{References}

Acton, R., \& Glasgow, P. (2015). Teacher wellbeing in neoliberal contexts: a review of the literature, Australian Journal of Teacher Education, 40-8, 1-17.

Ainscow, M., \& Sandill, A. (2010). Developing inclusive education systems: the role of organisational cultures and leadership, International Journal of Inclusive Education, 14 (4) 401-416.

Anderson, C. J. K., Klassen, R. M., \& Georgiou, G. K. (2007). Inclusion in Australia: What teachers say they need and what school psychologists can offer. School Psychology International 28-2, 131-47.

Board of studies, teaching and educational standards. (2013). Great teaching inspired learning. Retrieved 4 August 2015, from http://www.nswteachers.nsw.edu.au/greatteaching-inspired-learning/blueprint-for-action/resources/

Bruveris, I., \& Ozers, L. (1986). Building appropriate Classroom management eco-systems (BACME), Sydney, DSE Liverpool Region

Department of education and communities. (2011). Educational services supporting students with disabilities. Retrieved 4 February 2016, from www.schools.nsw.edu.au/media/ downloads/schoolsweb/stsupport/programs/disabilitypgrms 
Department of education and communities. (2003). Quality teaching in NSW schools. Retrieved 7 September 2015, from http://www.darcymoore.net/wp-content/uploads/ 2012/02/qt_EPSColor.pdf

Department of education and communities. (2012). Every Student, Every School: Learning and Support. Retrieved 29 August, 2015, from www.det.nsw.edu.au/media/ downloads/about-us/how-we-operate/national-partnerships-program/every-studentevery-school

Department of education and communities. (2015). Wellbeing for Schools. Retrieved 4 March 2016, from https://www.det.nsw.edu.au/wellbeing

Department of education and communities. (2010). Bullying: Preventing and responding to bullying in schools policy, guidelines and template. Retrieved 14 August, 2015, from www.det.nsw.edu.au/policies/student.../bullying

Department of education and communities. (2014). Student Discipline in government schools, policy and support material. Retrieved 4 March, 2016 from www.det.nsw.edu.au/ policies/

Department of education and communities. (2006). Professional Learning Policy for Schools. Retrieved March 4, 2016 from www.det.nsw.edu.au/policies/ https://www.det.nsw.edu. au/media/downloads/strat_direction/strat_plans/disaplan.pdf

Department of education and communities. (2011). Disability Action Plan 2011-201. Retrieved 4 July, 2015, from www.det.nsw.edu.au/media/downloads/

Department of education and communities. (2015). Behaviour Code for Students. Retrieved 5 November 2015, from http://www.dec.nsw.gov.au/about-the-department/our-reforms/ supported-students-successful-students/behaviour-code-

Department of education and training. (1995). Strategies for Safer Schools. NSW: Government Printer.

Department of education and training. (1996). Good Discipline and Effective Learning. Retrieved 27 August, 2015, from https://www.det.nsw.edu.au/policies/student serv/discipline/disc_minist/pd02_73_discminister.pdf

Department of education and training. (2003). Quality teaching in NSW public schools, discussion paper. Retrieved 5 March, 2016 from www.curriculumsupport.education. nsw.gov.au

Dinham, S. (2008). What do we know about student achievement? In Dinham, S. How to get your school moving and improving: An Evidence-based Approach, Camberwell, Victoria: ACER Press, 1-19.

Farmer, T. W., Reinke, W. M., \& Brooks, D. S. (2014). Managing classrooms and challenging behavior: Theoretical considerations and critical issues, Journal of Emotional and Behavior Disorders, 22-2, 67-73.

Florian, L. (2008). Special or inclusive education: future trends, British Journal of Special Education, 35-4, 202-208.

Fullan, M., \& Hargreaves, A. (Eds.) (1992). Teacher development and educational change, London: Falmer Press.

Gulson, K. V. (2007). Neoliberal spatioal technologies: on the practices of educational policy change, Critical Studies in Education, 48-2, 179-195.

Hall, G. E., \& Hord, S. M. (2001). Implementing change. Boston: Allyn and Bacon.

Hansen, J. H. (2012). Limits to inclusion, International Journal of Inclusive Education, 16 (1), 89-98.

Hatswell, J., \& Hinder, T. (1988). Working Ideas for Needs Satisfaction. West Pennant Hills, NSW, WINS Pub. 
Gorranson, K., Nilholm, C., \& Karlsson, K. (2011). Inclusive education in Sweden? A critical analysis, International Journal of Inclusive Education, 15 (5) 541- 555.

Kauffman, J. M., \& Landrum, T. J. (2009). Characteristics of emotional and behavioral disorders of children and youth ( $9^{\text {th }}$ edition), Boston: Pearson/Merrill.

Melnick, S. A., \& Meister, D. G. (2008). A comparison of beginning and experienced teacher concerns, Educational Research Quarterly, 31 (3), 39-56.

Novoa, A., \& Yariv-Mashal, T. (2003). Comparative Research in Education: a mode of governance or a historical journey?, Comparative Education, 39(4), 423-438

Noyce, P. (1985). Preface, in Hannan, B. (Ed.), Democratic Curriculum: Essays on Schooling and Society, Allen \& Unwin, Sydney \& Victorian Secondary Teachers Association, Melbourne, 1-4.

Senge, P. M. (2014). The Dance of Change: Strategies and tools for building a learning organization, Crown Business

Slee, R. (2009). Beyond special and regular schooling? An inclusive education. International Studies in Sociology of Education, 18, 99-166.

Skrtic, T. (1991). The special education paradox: Equity as the way to excellence. Harvard Educational Review, 61, 148-206.

Sullivan, A. M., Johnson, B., Owens, L., \& Conway, R. (2014). Punish them or engage them? Teachers' views of unproductive student behaviours in the classroom, Australian Journal of Teacher Education, 39 (6) 43-56

Van Swet, J., Wichers-Bots, J., \& Brown, K. (2011). Solution- focused assessment: rethinking labels to support inclusive education, International Journal of Inclusive Education, 15 (9) 909-923.

Wilkinson, J. (2008). Education on Country and city NSW. Retrieved 22 August, 2015, from http://www.parliament.nsw.gov.au/prod/parlment/publications.nsf/key/EducationinCou ntryandCityNewSouthWales 